\title{
Asymmetric intramolecular Pd(II)-catalysed oxycarbonylation of alkene-1,3-diols
}

\author{
Peter Kapitán and Tibor Gracza* \\ Department of Organic Chemistry, Institute of Organic Chemistry, Catalysis and \\ Petrochemistry, Slovak University of Technology, Radlinského 9, SK-812 37 Bratislava, Slovakia \\ E-mail: tibor.gracza@stuba.sk
}

\section{Dedicated to Professor Arlette Solladie-Cavallo on her $\mathbf{7 0}^{\text {th }}$ birthday}

\begin{abstract}
The first example of asymmetric oxycarbonylative bicyclisation of racemic pent-4-ene-1,3-diol $( \pm)$-1 catalysed by palladium(II) with chiral bis(oxazoline) ligands was investigated. The kinetic resolution of $( \pm)-\mathbf{1}$ in the presence of chiral catalyst, $p$-benzoquinone in acetic acid under carbon monoxide atmosphere (balloon) afforded both optically enriched 2,6-dioxabicyclo[3.3.0]octan-3ones $(R, R)$-2 and $(S, S)$-2, respectively.
\end{abstract}

Keywords: Asymmetric catalysis, kinetic resolution, oxycarbonylation, chiral bis(oxazolines), chiral Pd(II)-complexes

\section{Introduction}

Intramolecular palladium(II)-catalysed oxycarbonylation of unsaturated polyols is an important transformation of alkenes into bisheterocyclic lactones. ${ }^{1}$ The first examples of this domino reaction $\mathrm{Pd}(\mathrm{II})$-promoted cyclisation - intramolecular oxycarbonylation were described for 1,4and 1,3-alkenediols providing cis-fused bicyclic lactones, and involving tetrahydropyran ${ }^{2}$ and/or

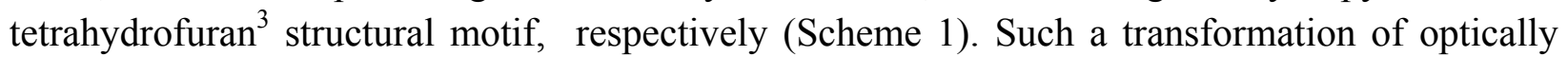
pure substrates has found numerous applications as the key step in the total syntheses of natural compounds (goniofufurone, ${ }^{4 \mathrm{a}, \mathrm{b}}$ goniothalesdiol, ${ }^{4 \mathrm{c}, \mathrm{d}}$ erythroskyrine, ${ }^{4 \mathrm{e}}$ kumausyne, ${ }^{4 \mathrm{f}}$ Hagen's gland lactones, ${ }^{4 \mathrm{~g}}$ and/or plakortones ${ }^{4 \mathrm{~h}-\mathrm{j}}$ ). 


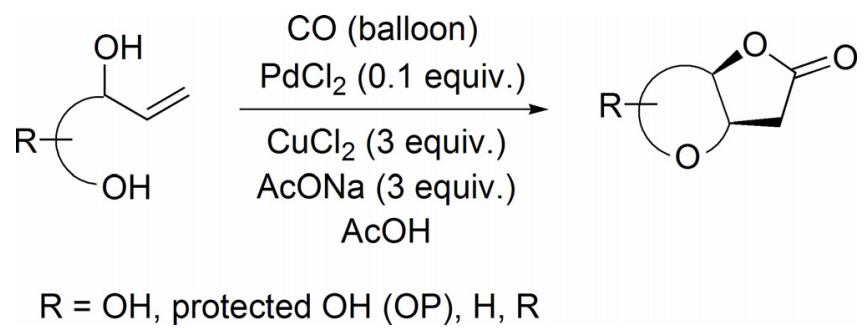

Scheme 1. Intramolecular Pd(II)-catalysed oxycarbonylation of unsaturated polyols.

Typically, alkoxycarbonylation of alkenyl alcohols is catalysed by $10 \mathrm{~mol} \%$ of the palladium(II)-salt in the presence of an oxidant $\left(\mathrm{CuCl}_{2}, p\right.$-benzoquinone, $\left.\mathrm{O}_{2}\right)$. Generally, the most efficient catalytic system for intramolecular oxycarbonylation of unsaturated polyols, originally developed for the Wacker process, contains palladium(II) chloride as a catalyst, copper(II) chloride as an oxidant, sodium acetate in acetic acid as a buffer, the reaction taking place under carbon monoxide atmosphere (balloon) at room temperature. In accordance with the diastereoselective cis-ring formation, racemic pent-4-ene-1,3-diol ( \pm -1 $\mathbf{1}$ afforded under these reaction conditions racemic 2,6-dioxabicyclo[3.3.0]octan-3-one $( \pm)-2$ in $60 \%$ yield. ${ }^{3}$ An asymmetric version of this type reaction has not been reported so far. To the best of our knowledge, previously reported works on related asymmetric Wacker-type oxidations have been limited to the monocyclisation of alkenes and alkynes. For instance, Kato, Akita et al. ${ }^{5}$ described desymmetrisation of cyclic meso-2-methyl-2-propargyl-1,3-cyclohexane-diols ${ }^{5, \mathrm{c}}$ and -1,3diones $^{5 b}$ using methoxycarbonylation catalysed with palladium(II)-complex, bearing chiral bis(oxazoline) ligands. Chiral bis(oxazolines) based on binaphtyl (Boxaxs ${ }^{6}$ ) or biphenyl backbone $^{7}$ were also successfully applied in the asymmetric Wacker-type cyclisation of allylphenols. ${ }^{8}$ Sasai and co-workers ${ }^{9}$ reported oxidative cyclisation of alkenyl alcohols ${ }^{9 a, b}$ and aminoalkenes ${ }^{9 \mathrm{c}}$ with spiro bis(isoxazolines) $\left(\mathrm{SPRIXs}^{9 \mathrm{~d}}\right.$ ). There is no report in the literature dealing with enantioselective oxycarbonylative bicyclisation of unsaturated polyols. We wish to report here the first example of kinetic resolution of alkene-diol by intramolecular Pd(II)catalysed oxycarbonylation.

\section{Results and Discussion}

Firstly, the catalytic system for kinetic resolution of unsaturated diols was examined. The racemic pent-4-ene-1,3-diol ${ }^{10}( \pm)-\mathbf{1}$ has been chosen as a model substrate for screening the reaction conditions. The transformation was carried out with different chiral $\operatorname{PdX}_{2}-[(R, S)-$ indabox] complexes, $p$-benzoquinone in acetic acid under carbon monoxide atmosphere (balloon). Chiral palladium(II)-complexes were generated in situ from $\mathrm{PdX}_{2}$ and a slight excess of chiral ligand $\mathbf{A}\{(3 \mathrm{a} R, 8 \mathrm{a} S)$-(8,8a-dihydro-3a $H$-indeno[1,2- $d]$ oxazol-2-yl $\}$ methane $[(R, S)$ indabox]. In accordance with a kinetic resolution process, the reaction was performed with $50 \%$ 
conversion by use of 0.5 equivalent of $p$-benzoquinone. Conversion control was made by GC with methyl benzoate as an internal standard. The reaction was quenched after $50 \%$ of the starting material had been consumed. The bicyclic product $\mathbf{2}$ and the remaining diol $\mathbf{1}$ were separated by flash chromatography. The enantiomeric excess of lactone $(R, R)-\mathbf{2}$ was determined by GC analysis with a chiral stationary phase (BGB 175 and BGB 173 column). The absolute configuration of $(R, R)-\mathbf{2}$ was assigned by comparison of the specific rotation value with the literature data $\left([a]_{D}^{20}=+62\left(\mathrm{c} 0.9, \mathrm{CHCl}_{3}\right)\right.$ for $(R, R)-2$ prepared from D-glucose ${ }^{11}[a]_{D}^{20}=-67(\mathrm{c}$ $\left.0.639, \mathrm{CHCl}_{3}\right)$ for $(S, S)-2$ prepared by microbial regiodivergent Baeyer-Villiger oxidation with $\left.99 \% e e^{12}\right)$.

As shown in Table 1, the reaction catalysed with $\operatorname{PdCl}_{2}-\{(R, S)$-indabox $(\mathbf{A})\}$ (entry 1) and $\operatorname{Pd}\left(\mathrm{BF}_{4}\right)_{2}-\{(R, S)$-indabox $\}$ complexes (entry 4) afforded only racemic lactone 2 . Moderate selectivities were achieved using $\mathrm{Pd}(\mathrm{OAc})_{2}-\{(R, S)$-indabox $\}$ (entry 2$)$ and $\mathrm{Pd}\left(\mathrm{OCOCF}_{3}\right)_{2}-\{(R, S)$ indabox \} catalysts (entry 3 ). It is apparent that catalytic activity of palladium complexes in the present reaction was strongly dependent upon the nature of the anionic part of the catalyst.

It is notable that in transformation of $\mathbf{1}$ to $\mathbf{2}$ the use of dichloromethane or tetrahydrofuran as solvents did not give satisfactory results in terms of both conversion and enantioselectivity.

Table 1. Kinetic resolution of pent-4-ene-1,3-diol ( \pm )-1 in asymmetric $\mathrm{Pd}(\mathrm{II})$-catalysed oxycarbonylation

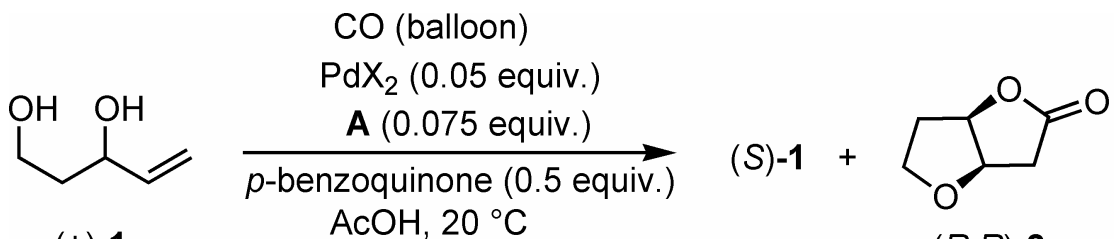

$( \pm)-1$
$\mathrm{AcOH}, 20^{\circ} \mathrm{C}$

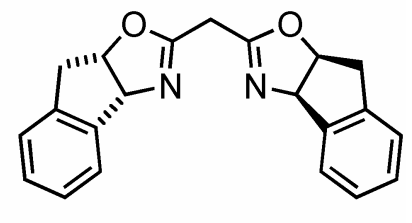

A $\{(R, S)$-indabox $\}$

\begin{tabular}{cccccccc}
\hline & \multicolumn{5}{c}{ Diol 1 } & \multicolumn{3}{c}{ Lactone 2 } \\
\hline Entry & $\mathrm{X}$ & $\begin{array}{c}\text { Reaction }^{\mathrm{a}} \\
\text { time }^{\mathrm{a}}\end{array}$ & $\begin{array}{c}\text { Yield }^{\mathrm{b}} \\
(\%)\end{array}$ & $\begin{array}{c}\text { Yield }^{\mathrm{b}} \\
(\%)\end{array}$ & $\%$ ee & {$[\alpha]_{\mathrm{D}}\left(25{ }^{\mathrm{o}} \mathrm{C}\right)$} & Configuration \\
\hline 1 & $\mathrm{Cl}$ & $120 \mathrm{~h}$ & 58 & 23 & $<5$ & $+1\left(0.25, \mathrm{CHCl}_{3}\right)$ & - \\
2 & $\mathrm{OAc}_{3}$ & $30 \mathrm{~h}$ & 48 & 33 & 43 & $+19\left(0.41, \mathrm{CHCl}_{3}\right)$ & $1 R, 5 R$ \\
3 & $\mathrm{OCOCF}_{3}$ & $30 \mathrm{~h}$ & 48 & 22 & 33 & $+16\left(0.26, \mathrm{CHCl}_{3}\right)$ & $1 R, 5 R$ \\
4 & $\mathrm{BF}_{4}$ & $120 \mathrm{~h}$ & 33 & 31 & $<5$ & $+3\left(0.40, \mathrm{CHCl}_{3}\right)$ & $1 R, 5 R$ \\
\hline
\end{tabular}

${ }^{a}$ Reaction was treated after $50 \%$ of starting material had been consumed (GC control).

${ }^{\mathrm{b}}$ Isolated yield after flash column chromatography.

${ }^{b}$ Enantiomeric excesses were determined using gas chromatography with chiral stationary phase.

Having found reaction conditions for a kinetic resolution process of the diol ( \pm )-1 by $\operatorname{Pd}(\mathrm{II})$ catalysed oxycarbonylation, our attention was turned to the screening of chiral ligands (Scheme 
2). Chiral $\mathrm{C}_{2}$-symmetric bisoxazolines have been chosen due to their ability to create stable palladium(II)-complexes. ${ }^{13,14}$

The reaction was carried out under optimised reaction conditions for kinetic resolution of $( \pm)$-1 using $5 \mathrm{~mol} \%$ of $\mathrm{Pd}(\mathrm{OAc})_{2}$ and $7.5 \mathrm{~mol} \%$ of ligands $\mathbf{A}-\mathbf{H}$ in glacial acetic acid, respectively. A cationic ${ }^{6 \mathrm{~b}}$ acetate complex $\mathrm{Pd}-(\mathrm{OAc})_{2}-\{(R, S)$-indabox $\mathbf{A}\}$ was found to be catalytically so highly active that the amount of the catalyst could be reduced to $2.5 \mathrm{~mol} \%$. The conversion was controlled by the amount of reoxidant ( 0.5 equivalents of $p$-benzoquinone). After completion the reaction, the solids were filtered off, solvent was evaporated and the product and remaining substrate were separated by flash column chromatography of the crude reaction mixture. The enantiomeric excesses and absolute configurations of lactones 2 were determined as above. The absolute configurations of lactones $\mathbf{4}$ and $\mathbf{6}$ were established by comparison of their specific rotation values with the literature data for $(R, R, R)-4:[a]_{D}^{22}=+46.5\left(\mathrm{c} 1.5, \mathrm{CHCl}_{3}\right)$ prepared from $(R)$-hexanediol; ${ }^{4 \mathrm{~g}}[a]_{D}^{25}=+51\left(\mathrm{c} 1, \mathrm{CHCl}_{3}\right)$ from D-glucose; ${ }^{15}$ for $(R, R, R)-\mathbf{6}$ : $[a]_{D}^{22}=$ +39.7 (c 1.05, $\left.\mathrm{CHCl}_{3}\right)$ from $(3 R, 5 R)$-undec-1-ene-3,5-diol; ${ }^{4 \mathrm{~g}}[a]_{D}^{25}=+50\left(\mathrm{c} 1, \mathrm{CHCl}_{3}\right)$ from Dglucose. $^{15}$ The NMR spectral data were in good agreement with those reported in the literature. ${ }^{4 \mathrm{~g}, 15}$
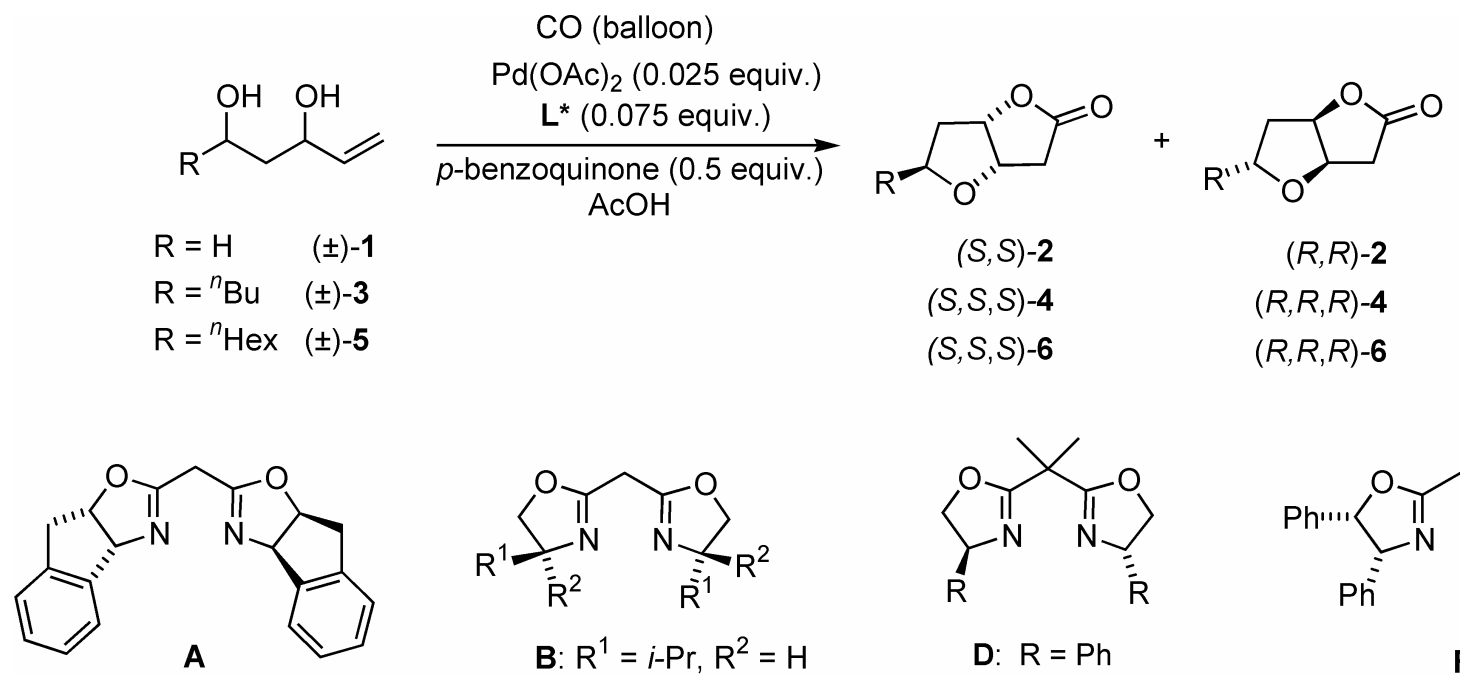

$$
\begin{aligned}
& \text { B: } \mathrm{R}^{1}=i-\operatorname{Pr}, \mathrm{R}^{2}=\mathrm{H} \\
& \text { C: } \mathrm{R}^{1}=\mathrm{H}, \mathrm{R}^{2}=i-\mathrm{Pr}
\end{aligned}
$$

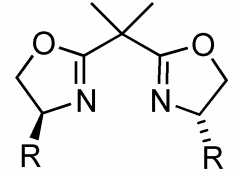

D: $\mathrm{R}=\mathrm{Ph}$

$\mathrm{E}: \mathrm{R}=t-\mathrm{Bu}$

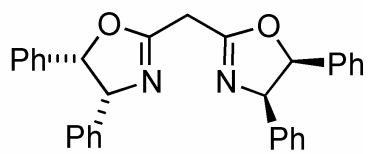

$\mathbf{F}$

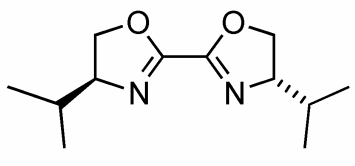

G

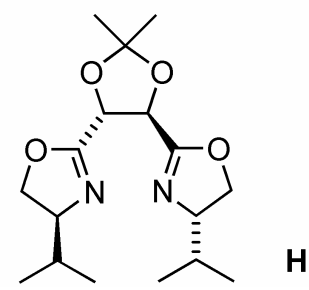

Scheme 2. Kinetic resolution of alkene-1,3-diols ( \pm )-1, $( \pm)-\mathbf{3}$ and ( \pm -5 in asymmetric $\operatorname{Pd}(\mathrm{II})$ catalysed oxycarbonylation. 
Table 2 summarises the results of a series of experiments with several $\mathrm{Pd}(\mathrm{OAc})_{2}\left(\mathrm{~L}^{*}\right)$ complexes. Generally, the enantioselectivity of the reaction was increased by the use of catalyst/ligand in a ratio 1:3. The best result was noted with $\mathrm{Pd}-(\mathrm{OAc})_{2}-\{(R, S)$-indabox $\}$ (entry 1). The $50 \%$ conversion of substrate was accomplished in $30 \mathrm{~h}$ at $18{ }^{\circ} \mathrm{C}$, and racemic diol $( \pm)-1$ was converted into bicyclic lactone $(R, R)-2$ in $29 \%$ yield and $62 \%$ ee. The use of palladium catalysts with ligands $\mathbf{B}, \mathbf{C}$ and $\mathbf{F}$ in the same reaction conditions furnished products $\mathbf{2}$ in comparable yields (28 - 33\%), but with lower enantioselectivity ( $40-45 \%$ ee, entries 2, 3 and 6 ). When the reaction was performed in the presence of ligands $\mathbf{D}, \mathbf{E}, \mathbf{G}$, and $\mathbf{H}$ the bicycle $\mathbf{2}$ was obtained with low selectivity, although these chiral bis(oxazolines) have been successfully used for other asymmetric transformations ${ }^{15}$ (entries 4, 5, 7 and 8). Similarly, the syn-enriched diols $( \pm)-3^{4 \mathrm{~g}}$ and $( \pm)-5^{4 \mathrm{~g}}$ (syn/anti, 85:15 for $( \pm)-\mathbf{3}, 86: 14$ for $( \pm)-5$, see experimental part) provided only the corresponding exo-lactones 4 and 6, respectively, with high diastereoselectivity and good yields (35-38\%, entries 9-12), however with low enantioselectivities. It is significant, that the reaction proceeding in the presence of $S$-configured bis(oxazoline) B provided enriched lactone $(S, S)-\mathbf{2}$, while the opposite enantiomer $\mathbf{C}$ preferred formation of $(R, R)-\mathbf{2}$.

Table 2. Screening of chiral bis(oxazoline) ligands in the asymmetric $\mathrm{Pd}(\mathrm{II})$-catalysed oxycarbonylation of alkene-1,3-diols $( \pm)-\mathbf{1},( \pm)-\mathbf{3}$ and $( \pm)-5$

\begin{tabular}{cccccccc}
\hline Entry & Diol & Ligand & Conditions & Lactone & $\begin{array}{c}\text { Yield }^{\mathrm{a}} \\
(\%)\end{array}$ & $\begin{array}{c}\% e^{\mathrm{b}} \\
{[\alpha]_{\mathrm{D}}\left(25^{\circ} \mathrm{C}\right)} \\
\left(c, \mathrm{CHCl}_{3}\right)\end{array}$ \\
\hline 1 & $( \pm)-\mathbf{1}$ & $\mathrm{A}^{\mathrm{c}}$ & $18{ }^{\circ} \mathrm{C}, 30 \mathrm{~h}$ & $(R, R)-\mathbf{2}$ & 29 & 62 & $+40(0.19)$ \\
2 & $( \pm)-\mathbf{1}$ & $\mathrm{B}^{16}$ & $18{ }^{\circ} \mathrm{C}, 48 \mathrm{~h}$ & $(S, S)-\mathbf{2}$ & 30 & 45 & $-20(0.28)$ \\
3 & $( \pm)-\mathbf{1}$ & $\mathrm{C}^{16}$ & $18{ }^{\circ} \mathrm{C}, 48 \mathrm{~h}$ & $(R, R)-\mathbf{2}$ & 33 & 45 & $+20(0.40)$ \\
4 & $( \pm)-\mathbf{1}$ & $\mathrm{D}^{\mathrm{c}}$ & $18{ }^{\circ} \mathrm{C}, 48 \mathrm{~h}$ & $\mathbf{2}$ & 31 & $<5$ & - \\
5 & $( \pm)-\mathbf{1}$ & $\mathrm{E}^{\mathrm{c}}$ & $40{ }^{\circ} \mathrm{C}, 48 \mathrm{~h}$ & $\mathbf{2}$ & 30 & 16 & - \\
6 & $( \pm)-\mathbf{1}$ & $\mathrm{F}^{\mathrm{c}}$ & $18{ }^{\circ} \mathrm{C}, 48 \mathrm{~h}$ & $(R, R)-\mathbf{2}$ & 28 & 40 & $+19(0.33)$ \\
7 & $( \pm)-\mathbf{1}$ & $\mathrm{G}^{16}$ & $18{ }^{\circ} \mathrm{C}, 48 \mathrm{~h}$ & $\mathbf{2}$ & 24 & $<5$ & - \\
8 & $( \pm)-\mathbf{1}$ & $\mathrm{H}^{16}$ & $18{ }^{\circ} \mathrm{C}, 48 \mathrm{~h}$ & $\mathbf{2}$ & 22 & $<5$ & - \\
9 & $( \pm)-\mathbf{3}$ & $\mathrm{A}^{\mathrm{c}}$ & $18^{\circ} \mathrm{C}, 48 \mathrm{~h}$ & $(R, R, R)-\mathbf{4}$ & 36 & 31 & $+15(0.41)$ \\
10 & $( \pm)-\mathbf{3}$ & $\mathrm{B}^{16}$ & $18{ }^{\circ} \mathrm{C}, 48 \mathrm{~h}$ & $(S, S, S)-\mathbf{4}$ & 36 & 9 & - \\
11 & $( \pm)-\mathbf{5}$ & $\mathrm{A}^{\mathrm{c}}$ & $18{ }^{\circ} \mathrm{C}, 30 \mathrm{~h}$ & $(R, R, R)-\mathbf{6}$ & 38 & 41 & $+17(0.35)$ \\
12 & $( \pm)-\mathbf{5}$ & $\mathrm{B}^{16}$ & $18^{\circ} \mathrm{C}, 48 \mathrm{~h}$ & $\mathbf{6}$ & 35 & $<5$ & - \\
\hline
\end{tabular}

${ }^{a}$ Isolated yield after flash column chromatography.

${ }^{\mathrm{b}}$ Enantiomeric excesses were determined using gas chromatography with chiral stationary phase.

${ }^{\mathrm{c}}$ Commercially available. 


\section{Conclusions}

In summary, we have presented a kinetic resolution process of racemic alkene-1,3-diols $( \pm)-1$, $( \pm)-\mathbf{3}$ and $( \pm)-\mathbf{5}$ catalysed by palladium(II) with chiral bis(oxazolines). This is the first report of an enantioselective oxycarbonylative bicyclisation. Conversion of substrate is controlled by reoxidant, which represents novelty in kinetic resolution processes. Further studies to improve the performance of asymmetric catalysts for this transformation are now under way.

\section{Experimental Section}

General Procedures. Commercial reagents were used without further purification. All solvents were distilled before use. Hexanes refer to the fraction boiling at $60-65^{\circ} \mathrm{C}$. Flash column liquid chromatography (FLC) was performed on silica gel Kieselgel 60 (40-63 $\mu \mathrm{m}, 230-400 \mathrm{mesh}$ ) and analytical thin-layer chromatography (TLC) was performed on aluminium plates pre-coated with either $0.2 \mathrm{~mm}$ (DC-Alufolien, Merck) or $0.25 \mathrm{~mm}$ silica gel $60 \mathrm{~F}_{254}$ (ALUGRAM $^{\circledR}$ SIL G/UV 254 , Macherey-Nagel). General conversion control and analyses of purified products were performed on a GC Top 8000/MS Voyager (quadropol, EI+) using a standard capillary column BGB5 (30 $\mathrm{mP0} 0.32 \mathrm{~mm}$ ID). Enantiomeric excesses were determined by chiral-phase GC using a BGB 175 column (30 mP $0.25 \mathrm{~mm}$ ID, $0.25 \mathrm{~mm}$ film, 50\% 2,3-diacetyl-6-tert-butyldimethylsilylated- $\gamma$ cyclodextrin dissolved in BGB-1701 (14\% cyanopropylphenyl-, 86\% methylpolysiloxane)) and a BGB 173 column (30 mP $0.25 \mathrm{~mm}$ ID, $0.25 \mathrm{~mm}$ film, 50\% 2,3-diacetyl-6-tertbutyldimethylsilylated- $\alpha$-cyclodextrin dissolved in BGB-1701 (14\% cyanopropylphenyl-, 86\% methylpolysiloxane)) on a ThermoQuest Trace GC 2000 and a Thermo Focus GC. Optical rotations were measured with the POLAR L- $\mu$ P polarimeter (IBZ Messtechnik) with a waterjacketed $10.000 \mathrm{~cm}$ cell at the wavelength of sodium line $\mathrm{D}(\lambda=589 \mathrm{~nm})$. Specific rotations are given in units of $10^{-1} \mathrm{deg} \mathrm{cm}^{2} \cdot \mathrm{g}^{-1}$ and concentrations are given in $\mathrm{g} / 100 \mathrm{~mL}$. Elemental analyses were run on FISONS EA1108 instrument. Infrared spectra were recorded on a Philips Analytical PU9800 FTIR spectrometer as $\mathrm{KBr}$ discs $(\mathrm{KBr})$ or as thin films on $\mathrm{KBr}$ plates (film). NMR spectra were recorded on a Varian VXR-300 spectrometer. Chemical shifts $(\delta)$ are quoted in ppm and are referenced to the tetramethylsilane (TMS) as internal standard. The multiplicites of carbons were assigned from a broadband decoupled analysis used in conjuction with either APT or DEPT programs.

( \pm )-Non-1-ene-3,5-diol $(( \pm)-3)$. DIBAL-H $(16 \mathrm{~mL}, 1 \mathrm{M}$ in hexane, 2.5 equiv.) was added to a solution of $( \pm)$-3-hydroxynon-1-en-5-one ${ }^{4 \mathrm{~g}}(1.0 \mathrm{~g}, 6.5 \mathrm{mmol})$ in anhydrous THF $(50 \mathrm{~mL})$ at $90^{\circ} \mathrm{C}$ during $30 \mathrm{~min}$. The reaction mixture was stirred for additional $2 \mathrm{~h}$ at $-90^{\circ} \mathrm{C}$, quenched with $\mathrm{HCl}(2 \mathrm{M}, 25 \mathrm{~mL})$ and extracted with AcOEt $(3 \times 20 \mathrm{~mL})$. Organic phases were dried over $\mathrm{Na}_{2} \mathrm{SO}_{4}$ and concentrated in vacuo. Analytically pure product $( \pm)-\mathbf{3}$ as the mixture of diastereomers (syn/anti, 85:15 by ${ }^{13} \mathrm{C}$ NMR) was obtained by FLC (30 g of silica-gel, AcOEt-hexanes, 1:6) as 
colourless oil (850 mg, 84\%); $\mathrm{R}_{\mathrm{f}} 0.45$ (AcOEt-hexanes, 1:3). Anal. calcd. for $\mathrm{C}_{9} \mathrm{H}_{18} \mathrm{O}_{2}$ (158.24): C 68.31, H 11.47; found: C 68.42, H 11.43. Spectral data were in full accordance with lit. ${ }^{4 \mathrm{~g}}$

( \pm )-Undec-1-ene-3,5-diol $(( \pm)-5)$. The procedure described above was applied for conversion of $( \pm)$-3-hydroxyundec-1-ene-5-one ${ }^{4 \mathrm{~g}, 17}(2.5 \mathrm{~g}, 13.4 \mathrm{mmol})$ to nonene-3,5-diol $( \pm)-5$. The crude product was purified by flash column chromatography (50 g of silica-gel, AcOEt/hexanes, 1:6); yield $1.9 \mathrm{~g}(76 \%)$ of $( \pm)-5$, colourless oil, $\mathrm{R}_{\mathrm{f}} 0.27$ (AcOEt-hexanes, 1:1). The product consisted of a 86:14 syn/anti diastereomers $( \pm)-5$ (determined by $\left.{ }^{13} \mathrm{C}-\mathrm{NMR}\right) .{ }^{1} \mathrm{H}-\mathrm{NMR}\left(\mathrm{CDCl}_{3}, 300 \mathrm{MHz}\right.$, major diastereomer) $\delta 0.88\left(\mathrm{t}, 3 \mathrm{H}, J_{10,11}=7 \mathrm{~Hz}, \mathrm{H}-11\right), 1.28-1.70(\mathrm{~m}, 12 \mathrm{H}, \mathrm{H}-4, \mathrm{H}-6, \mathrm{H}-7, \mathrm{H}-8$, H-9, H-10), 3.61 (bs, 2H, OH), 3.85-3.90 (m, 1H, H-5), 4.32-4.38 (m, 1H, H-3), 5.85 (dt, 1H, $\left.J_{1 Z, 2}=11 \mathrm{~Hz}, J_{1 \mathrm{Z}, 1 \mathrm{E}}=1 \mathrm{~Hz}, \mathrm{H}-1 \mathrm{Z}\right), 5.24\left(\mathrm{dt}, 1 \mathrm{H}, J_{1 \mathrm{E}, 2}=18 \mathrm{~Hz}, J_{1 \mathrm{Z}, 1 \mathrm{E}}=1 \mathrm{~Hz}, \mathrm{H}-1 \mathrm{E}\right), 5.81-5.92$ (m, 1H, H-2); ${ }^{13} \mathrm{C}-\mathrm{NMR}\left(\mathrm{CDCl}_{3}, 75 \mathrm{MHz}\right.$, major diastereomer) $\delta 14.1$ (q, C-11), 22.6, 25.3, 29.3, 31.8, 38.1, 42.7 (all t, C-4, C-6, C-7, C-8, C-9, C-10), 72.5, 73.8 (all d, C-3, C-5), 114.4 (t, C-1), 140.7 (d, C-2). IR (film, $\mathrm{cm}^{-1}$ ): $v$ 3346, 2956, 2930, 2858, 1466, 1423. Anal. calcd. for $\mathrm{C}_{11} \mathrm{H}_{22} \mathrm{O}_{2}$ (186.16): C 70.92, H 11.90; found: C 70.86, H 11.95. This compound ( \pm )-5 was previously used in the next reaction without characterisation. ${ }^{4 \mathrm{~g}}$

A typical procedure for asymmetric oxycarbonylation of alkenediols $( \pm)-1,( \pm)-3,( \pm)-5$ with $\left(\mathrm{L}^{*}\right) \mathrm{Pd}(\mathrm{OAc})_{2},\left(\mathrm{~L}^{*}\right) \mathrm{Pd}\left(\mathrm{OCOCF}_{3}\right)_{2}$ and $\left(\mathrm{L}^{*}\right) \mathrm{PdCl}_{2}$

Chiral ligand $(0.075 \mathrm{mmol})$ in $\mathrm{AcOH}(1 \mathrm{ml})$ was added to the solution of $\mathrm{Pd}(\mathrm{OAc})_{2}$, or $\mathrm{Pd}\left(\mathrm{MeCN}_{2} \mathrm{Cl}_{2}\right.$ (0.05 mmol, 0.05 equiv. or $0.025 \mathrm{mmol}, 0.025$ equiv.) in DCM (1 ml), respectively. The mixture was stirred for $15 \mathrm{~min}$ to give a clear solution and DCM was removed in vacuo. Resulting chiral palladium complex was dissolved in glacial $\mathrm{AcOH}(2 \mathrm{ml})$, substrate ( \pm -1 $(1.0 \mathrm{mmol})$ and $p$-benzoquinone $(0.5$ equiv.) in $\mathrm{AcOH}(2 \mathrm{ml})$ were added. The flask was purged with $\mathrm{CO}$ from a balloon and the reaction mixture was vigorously stirred until the deposition of black palladium was observed (approx. 1-2 days). The solvent was evaporated and the crude product purified by flash column chromatography.

\section{Asymmetric oxycarbonylation with $( \pm)-1\left(\mathrm{~L}^{*}\right) \mathbf{P d}\left(\mathrm{BF}_{4}\right)_{2}$}

Chiral ligand $(0.075 \mathrm{mmol})$ in DCM $(1 \mathrm{ml})$ was added to the solution of $\mathrm{Pd}(\mathrm{MeCN})_{2} \mathrm{Cl}_{2}(0.05$ mmol, 0.05 equiv.) in DCM $(1 \mathrm{ml})$. The mixture was stirred for $15 \mathrm{~min}$ to give clear solution. This solution was added to a mixture of $\mathrm{AgBF}_{4}(0.05 \mathrm{mmol})$ in $\mathrm{DCM}(1 \mathrm{ml})$. Precipitated $\mathrm{AgCl}$ was removed by filtration and the filtrate was concentrated. The solid was dissolved in glacial $\mathrm{AcOH}(2 \mathrm{ml})$ and substrate $( \pm)-1(1.0 \mathrm{mmol})$ and $p$-benzoquinone $(0.5$ equiv.) in $\mathrm{AcOH}(2 \mathrm{ml})$ were added. The flask was purged with $\mathrm{CO}$ from balloon and the mixture was vigorously stirred until black palladium was observed (approx. 1 day). The solvent was then evaporated and the crude product purified by flash column chromatography.

$(1 R, 5 R)$ - and $(1 S, 5 S)-2,6-D i o x a b i c y c l o[3.3 .0]$ octane-3-one $\{(R, R)-2$ and $(S, S)-2\}$. Prepared as described above. Colorless oil, $\mathrm{R}_{\mathrm{f}} 0.30$ (AcOEt-hexanes, 1:1), yield, specific rotation value and \%ee see tables 1, 2; $\left\{\right.$ lit. $[a]_{D}^{20}=+62\left(\mathrm{c} 0.9, \mathrm{CHCl}_{3}\right)$ for $(R, R)-2$ prepared from D-glucose; ${ }^{11}[a]_{D}^{20}=$ $-67\left(\mathrm{c} 0.639, \mathrm{CHCl}_{3}\right)$ for $(S, S)-2$ prepared by microbial regiodivergent Baeyer-Villiger oxidation 
with 99\% ee $\left.e^{12}\right\} .{ }^{1} \mathrm{H}-\mathrm{NMR}\left(\mathrm{CDCl}_{3}, 300 \mathrm{MHz}\right) \delta 2.05-2.40(\mathrm{~m}, 2 \mathrm{H}, \mathrm{H}-8), 2.66(\mathrm{~d}, \mathrm{~A}$ of $\mathrm{ABX}, 1 \mathrm{H}$, $\left.J_{\mathrm{A}, \mathrm{B}}=19 \mathrm{~Hz}, \mathrm{H}-4 \mathrm{~A}\right), 2.80\left(\mathrm{dd}, \mathrm{B}\right.$ of $\left.\mathrm{ABX}, 1 \mathrm{H}, J_{\mathrm{A}, \mathrm{B}}=19 \mathrm{~Hz}, J_{\mathrm{B}, 5}=6 \mathrm{~Hz}, \mathrm{H}-4 \mathrm{~B}\right), 3.90-4.00(\mathrm{~m}$, $2 \mathrm{H}, \mathrm{H}-7), 4.70\left(\mathrm{dd}, \mathrm{dX}\right.$ of ABX, $\left.1 \mathrm{H}, J_{\mathrm{B}, 5}=J_{1,5}=5 \mathrm{~Hz}, \mathrm{H}-5\right), 5.13\left(\mathrm{dd}, 1 \mathrm{H}, J_{5,8}=J_{1,5}=5 \mathrm{~Hz}, \mathrm{H}-\right.$ 1); ${ }^{13} \mathrm{C}-\mathrm{NMR}\left(\mathrm{CDCl}_{3}, 75 \mathrm{MHz}\right) \delta 32.9(\mathrm{t}, \mathrm{C}-8), 32.6(\mathrm{t}, \mathrm{C}-4), 66.9(\mathrm{t}, \mathrm{C}-7), 78.0(\mathrm{~d}, \mathrm{C}-5), 84.3$ (d, C-1), 175.8 (s, C-3). IR (film, $\mathrm{cm}^{-1}$ ): $v$ 2966, 2869, 1777. GC/MS for $\mathrm{C}_{6} \mathrm{H}_{8} \mathrm{O}_{3}\left(\mathrm{M}^{+1}\right)$ : calcd. 128.05, found 129 .

$(1 R, 5 R, 7 R)-$ and $(1 S, 5 S, 7 S)-7-B u t y l-2,6-d i o x a b i c y c l o[3.3 .0]$ octane-3-one $\{(R, R, R)-4$ and $(S, S, S)-4\}$. Prepared according to the typical procedure for asymmetric oxycarbonylation from diol ( \pm )-3 using $\mathrm{Pd}(\mathrm{OAc})_{2}(0.025 \mathrm{mmol})$, ligand $\mathbf{A}$ and $\mathbf{B}$, respectively (Table 2, entries 9 and 10). Colorless oil, Rf 0.36 (AcOEt-hexanes, 1:2); $\left\{\right.$ lit.: ${ }^{4 \mathrm{~g}}[a]_{D}^{22}=+46.5\left(\mathrm{c} 1.5, \mathrm{CHCl}_{3}\right)$ for $(R, R, R)-$ 4 and $[a]_{D}^{22}=-47.5\left(\mathrm{c} 1.46, \mathrm{CHCl}_{3}\right)$ for $(S, S, S)-4$ prepared from $(R)$ - and $(S)$-hexanediol, respectively; lit.: ${ }^{15}[a]_{D}^{25}=+51\left(\mathrm{c} 1, \mathrm{CHCl}_{3}\right)$ for $(R, R, R)-4$ from D-glucose. ${ }^{1} \mathrm{H}-\mathrm{NMR}\left(\mathrm{CDCl}_{3}, 300\right.$ $\mathrm{MHz}) \delta 0.88\left(\mathrm{t}, 3 \mathrm{H}, J_{3^{\prime}, 4^{\prime}}=8 \mathrm{~Hz}, \mathrm{CH}_{3}\right), 1.21-1.38\left(\mathrm{~m}, 4 \mathrm{H}, \mathrm{CH}_{2}\right), 1.40-1.70\left(\mathrm{~m}, 3 \mathrm{H}, \mathrm{CH}_{2}, \mathrm{H}-8 \mathrm{~A}\right)$, $2.35\left(\mathrm{dd}, 1 \mathrm{H}, J_{8 \mathrm{~A}, 8 \mathrm{~B}}=14 \mathrm{~Hz}, J_{1,8 \mathrm{~B}}=4 \mathrm{~Hz}, \mathrm{H}-8 \mathrm{~B}\right), 2.61\left(\mathrm{~d}, 1 \mathrm{H}, J_{\mathrm{A}, \mathrm{B}}=18 \mathrm{~Hz}, \mathrm{H}-4 \mathrm{~A}\right), 2.74(\mathrm{dd}, \mathrm{B}$ of ABX, 1H, $\left.J_{\mathrm{A}, \mathrm{B}}=18 \mathrm{~Hz}, J_{\mathrm{B}, 5}=6 \mathrm{~Hz}, \mathrm{H}-4 \mathrm{~B}\right), 4.00-4.09(\mathrm{~m}, 1 \mathrm{H}, \mathrm{H}-7), 4.79$ (dd, dX of ABX, $\left.1 \mathrm{H}, J_{\mathrm{B}, 5}=J_{1,5}=6 \mathrm{~Hz}, \mathrm{H}-5\right), 5.10\left(\mathrm{dd}, 1 \mathrm{H}, J_{1,8}=J_{1,5}=4 \mathrm{~Hz}, \mathrm{H}-1\right) ;{ }^{13} \mathrm{C}-\mathrm{NMR}\left(\mathrm{CDCl}_{3}, 75 \mathrm{MHz}\right) \delta$ 14.0 (q, $\mathrm{CH}_{3}$ ), 22.6, 28.2, 34.4, 36.7, 38.8 (all t, 3xCH $2, \mathrm{C}-4$ ), 77.5 (d, C-7), 78.3 (d, C-5), 84.9 (d, C-1), 176.0 (s, C-3). IR (film, $\mathrm{cm}^{-1}$ ): $v$ 2959, 2927, 2856, 1770. GC/MS for $\mathrm{C}_{10} \mathrm{H}_{16} \mathrm{O}_{3}\left(\mathrm{M}^{+1}\right)$ : calcd. 184.11, found 185 .

$(1 R, 5 R, 7 R)-$ and $(1 S, 5 S, 7 S)-7-H e x y l-2,6-d i o x a b i c y c l o[3.3 .0]$ octane-3-one $\{(R, R, R)-6$ and $(S, S, S)-6\}$. Prepared according to the typical procedure for asymmetric oxycarbonylation from diol ( \pm )-5 using $\mathrm{Pd}(\mathrm{OAc})_{2}(0.025 \mathrm{mmol})$, ligand $\mathbf{A}$ and $\mathbf{B}$, respectively (Table 2, entries 11 and 12). Colorless oil, Rf 0.31 (AcOEt-hexanes, 1:2); $\left\{\right.$ lit.: ${ }^{4 \mathrm{~g}}[a]_{D}^{22}=+39.7$ (c 1.05, $\mathrm{CHCl}_{3}$ ) for $(R, R, R)-6$ and $[a]_{D}^{22}=-41.0\left(\mathrm{c} 1.02, \mathrm{CHCl}_{3}\right)$ for $(S, S, S)-6$ prepared from $(3 R, 5 R)$ - and $(3 S, 5 S)$ undec-1-ene-3,5-diol, respectively. ${ }^{1} \mathrm{H}-\mathrm{NMR}\left(\mathrm{CDCl}_{3}, 300 \mathrm{MHz}\right) \delta 0.88\left(\mathrm{t}, 3 \mathrm{H}, J_{5^{\prime}, 6^{\prime}}=8 \mathrm{~Hz}\right.$, $\left.\mathrm{CH}_{3}\right), 1.20-1.72\left(\mathrm{~m}, 11 \mathrm{H}, \mathrm{CH}_{2}, \mathrm{H}-8 \mathrm{~A}\right), 2.38\left(\mathrm{dd}, 1 \mathrm{H}, J_{8 \mathrm{~A}, 8 \mathrm{~B}}=14 \mathrm{~Hz}, J_{1,8 \mathrm{~B}}=5 \mathrm{~Hz}, \mathrm{H}-8 \mathrm{~B}\right), 2.70(\mathrm{~d}$, $\left.1 \mathrm{H}, J_{\mathrm{A}, \mathrm{B}}=19 \mathrm{~Hz}, \mathrm{H}-4 \mathrm{~A}\right), 2.78\left(\mathrm{dd}, \mathrm{B}\right.$ of $\left.\mathrm{ABX}, 1 \mathrm{H}, J_{\mathrm{A}, \mathrm{B}}=19 \mathrm{~Hz}, J_{\mathrm{B}, 5}=6 \mathrm{~Hz}, \mathrm{H}-4 \mathrm{~B}\right), 4.02-4.11$ (m, 1H, H-7), 4.80-4.84 (m,1H, H-5), $5.13\left(\mathrm{dd}, 1 \mathrm{H}, J_{1,8}=J_{1,5}=5 \mathrm{~Hz}, \mathrm{H}-1\right) ;{ }^{13} \mathrm{C}-\mathrm{NMR}\left(\mathrm{CDCl}_{3}, 75\right.$ $\mathrm{MHz}) \delta 14.1$ (q, $\mathrm{CH}_{3}$ ), 22.6, 26.0, 29.2, 31.7, 34.7, 36.7, 38.8 (all t, 5xCH $2, \mathrm{C}-4, \mathrm{C}-8$ ), 77.4 (d, C-7), 78.3 (d, C-5), 85.0 (d, C-1), 176.1 (s, C-3). IR (film, $\mathrm{cm}^{-1}$ ): v 2956, 2930, 2859, 1785, 1172. GC/MS for $\mathrm{C}_{12} \mathrm{H}_{20} \mathrm{O}_{3}\left(\mathrm{M}^{+1}\right)$ : calcd. 212.14, found 213 .

\section{Acknowledgements}

This work was supported by Slovak Grant Agencies (VEGA, Slovak Academy of Sciences and Ministry of Education, Bratislava, project No. 1/3549/06, and APVV, Bratislava, project No. APVV-20-000305). The authors are grateful to Prof. Marko D. Mihovilovic (Vienna University of Technology) for his help with the determination of enantiomeric purity and to Dr. Zalupsky (Department of Organic Chemistry, STU Bratislava) for helpful discussions. 


\section{References and Notes}

1. For reviews see: (a) Colquhoun, H. M.; Thompson, D. J.; Twigg, M. V. Carbonylation, Plenum Press: New York, 1991. (b) Tsuji, J. Palladium Reagents and Catalysts: New Perspective for the $21^{\text {st }}$ Century, John Wiley \& Sons: Chichester, 2004. (c) Schmalz, H. G.; Geis, O. In: Ei-ichi Negishi, Ed., Handbook of Organopalladium Chemistry for Organic Syntheses, John Wiley \& Sons, Inc.: New York, 2002; Vol. 2, p 2397. (d) Muzart, J. Tetrahedron 2005, 61, 5955. (e) Muzart, J. Tetrahedron 2005, 61, 9423. (f) Gracza, T.; Hasenöhrl, T.; Stahl, U.; Jäger, V. Synthesis 1991, 1108. (g) Jäger, V.; Gracza, T.; Dubois, E.; Hasenöhrl, T.; Hümmer, W.; Kautz, U.; Kirschbaum, B.; Lieberknecht, A.; Remen, L.; Shaw, D.; Stahl, U.; Stephan, O. In Pd(II)-Catalyzed Carbonylation of Unsaturated Polyols and Aminopolyols: Helmchen, G.; Dibo, J.; Flubacher, D.; Wiese, B. Eds. Organic Synthesis via Organometallics OSM 5. Vieweg: Braunschweig, 1997; pp 331.

2. Semmelhack, M. F.; Bodurow, Ch.; Baum, M. Tetrahedron Lett. 1984, 25, 3171.

3. Tamaru, Y.; Kobayashi, T.; Kawamura, S.-i.; Ochiai, H.; Hojo, M.; Yoshida, Z-i. Tetrahedron Lett. 1985, 26, 3207.

4. (a) Gracza, T.; Jäger, V. Synlett 1992, 191. (b) Gracza, T.; Jäger, V. Synthesis 1994, 1359.

(c) Babjak, M.; Kapitán, P.; Gracza, T. Tetrahedron Lett. 2002, 43, 6983. (d) Babjak, M.; Kapitán, P.; Gracza, T. Tetrahedron 2005, 61, 2471. (e) Dixon, D. J.; Ley, S. V.; Gracza, T.; Szolcsányi, P. J. Chem. Soc., Perkin Trans 1, 1999, 839. (f) Boukouvalas, J.; Fortier, G.; Radu, I.-I. J. Org. Chem. 1998, 63, 916. (g) Paddon-Jones, G. C.; McErlean. S. P.; Hayes, P.; Moore, C. J.; Konig, W. A.; Kitching, W. J. Org. Chem. 2001, 66, 7487. (h) Hayes, P. Y.; Kitching, W. J. Am. Chem. Soc. 2002, 124, 9718. (i) Semmelhack, M. F.; Shanmugam, P. Tetrahedron Lett. 2000, 41, 3567. (j) Semmelhack, M. F.; Hooley, R. J.; Kraml, Ch. M. Org. Lett. 2006, 8, 5203.

5. (a) Kato, K.; Tanaka, M.; Yamamoto, Y.; Akita, H. Tetrahedron Lett. 2002, 43, 1511. (b) Kato, K.; Tanaka, M.; Yamamura, S.; Yamamoto, Y.; Akita, H. Tetrahedron Lett. 2003, 44, 3089. (c) Kato, K.; Matsuba. C.; Kusakabe, T.; Takayama, H.; Yamamura, S.; Mochida, T.; Akita, H.; Peganova, T. A.; Vologdin, N. V.; Gusev, O. V. Tetrahedron 2006, 62, 9988.

6. (a) Uozumi, Y.; Kato, K.; Hayashi, T. J. Am. Chem. Soc. 1997, 119, 5063. (b) Uozumi, Y.; Kato, K.; Hayashi, T. J. Org. Chem. 1998, 63, 5071. (c) Uozumi, Y.; Kyota, H.; Kato, K.; Ogasawara, M.; Hayashi, T. J. Org. Chem. 1999, 64, 1620.

7. (a) Wang, F.; Zhang, Y. J.; Wei,H.; Zhang, J.; Zhang, W. Tetrahedron Lett. 2007, 48, 4083.

(b) Wang, F.; Zhang, Y. J.; Yang, G.; Zhang, W. Tetrahedron Lett. 2007, 48, 4179.

8. (a) Trend, R. M.; Ramtohul, Y. K.; Ferreira, E. M.; Stoltz, B. M. Angew. Chem. Int. Ed. 2003, 42, 2892. (b) Trend, R. M.; Ramtohul, Y. K.; Stoltz, B. J. Am. Chem. Soc. 2005, 127, 17778 .

9. (a) Arai, M. A.; Kuraishi, M.; Arai, T.; Sasai, H. J. Am. Chem. Soc. 2001, 123, 2907. (b) Koranne, P. S.; Tsujihara, T.; Arai, M. A.; Bajracharya, G. B.; Suzuki, T.; Onitsuka, K.; Sasai, H. Tetrahedron: Asymmetry 2007, 18, 919. (c) Shinohara, T.; Arai, M. A.; Wakita, 
K.; Arai, T.; Sasai, H. Tetrahedron Lett. 2003, 44, 711. (d) Arai, M. A.; Arai, T.; Sasai, H. Org. Lett. 1999, 1, 1795.

10. Kelly, D. R.; Nally, J. Tetrahedron Lett. 1999, 40, 3251.

11. Gurjar, M. K.; Patil, V. J.; Pawar, S. M. Carbohydr. Res. 1987, 165, 313.

12. (a) Mihovilovic, M. D.; Kapitán, P. Tetrahedron Lett. 2004, 45, 2751. (b) Petit, F.; Furstoss, R. Tetrahedron: Asymmetry 1993, 4, 1341.

13. Ghosh, A. K.; Mathivanan, P.; Cappiello, J. Tetrahedron: Asymmetry 1998, 9, 1.

14. (a) Fache, F.; Schulz, E.; Tommasino, L.; Lemaire, M. Chem. Rev. 2000, 100, 2159. (b) Desimoni, G.; Faita, G.; Jorgensen, K. A. Chem. Rev. 2006, 106, 3561.

15. (a) Mereyala, H. B.; Gadikota, R. R. Chem. Lett. 1999, 273. (b) Mereyala, H. B.; Gadikota, R. R.; Sunder, K. S.; Shailaja, S. Tetrahedron 2000, 56, 3021. (c) Mereyala, H. B.; Gadikota, R. R. Tetrahedron: Asymmetry 2000, 11, 743.

16. Bisoxazoline ligands $\mathbf{A}, \mathbf{D}, \mathbf{E}$ and $\mathbf{F}$ are commercially available and were purchased from Aldrich. Bis(oxazolines) $\mathbf{B}, \mathbf{C}, \mathbf{G}$ and $\mathbf{H}$ were synthesised by the described procedures; for ligands B, C, G see: Müller, D.; Umbricht, G.; Weber, B.; Pfaltz, A. Helv. Chim. Acta 1991, 74, 232; ligand H: Imai, Y.; Zhang, W.; Kida, T.; Nakatsuji, Y.; Ikeda, I. Tetrahedron: Asymmetry 1996, 7, 2453.

17. Das, N. B.; Torssell, K. B. G. Tetrahedron 1983, 39, 2247. 